\title{
\begin{tabular}{l|l|l} 
Jurnal Eksplorasi Akuntansi & $\begin{array}{l}\text { e-ISSN : 2656-3649 (Online) } \\
\text { Vol. 3, No 1, Februari 2021, Hal 203-217 }\end{array}$
\end{tabular}
}

\section{Pengaruh Strategi Bisnis dan Financial Leverage terhadap Manajemen Laba dengan Corporate Governance sebagai Variabel Moderasi}

\author{
Husnaini Dwi Wanri ${ }^{1}$, Erinos NR ${ }^{2}$ \\ 1,2 Jurusan Akuntansi Fakultas Ekonomi Universitas Negeri Padang \\ *Korespondensi: dwiwanri@gmail.com
}

\begin{abstract}
This study aims to examine the effect of business strategy and financial leverage as moderated by corporate governance in predicting real earnings management. This type of research is a causal association with a quantitative approach. The population used in this study are all manufacturing companies listed in Bursa Efek Indonesia 2016-2019. The sampling technique in this study using the purposive sampling technique, there are 80 manufacturing companies used as research samples. The business strategy variables are measured by the cost leadership strategy model for the current year. Earnings management variables are calculated by aggregating the triggering factors for earnings management, namely sales manipulation, overproduction, and discretionary spending. The leverage variable is calculated by the ratio of debt to assets and the moderating variable is measured by the proportion of share ownership by the managerial party. The data used in this study is secondary data obtained from the company's financial statements obtained from the official website of the Indonesia Stock Exchange and the official website of each company. The analytical method used is the multiple regression method which is processed using the SPSS 16 application. The results show that business strategy, financial leverage has a significant positive effect on real earnings management, $C G$ can increase or weaken the relationship between business strategy, leverage on real earnings management but not significantly.
\end{abstract}

Keywords: Business strategy; Leverage; Real earnings

\section{How to cite}

Wanri, H. D, \& NR, Erinos. (2021). Pengaruh Strategi Bisnis dan Financial Leverage Terhadap Manajemen Laba Dengan Corporate Governance Sebagai Variabel Moderasi (Studi Kasus Pada Perusahaan Manufaktur Yang Terdaftar Di Bursa Efek Indonesia Pada Tahun 2016-2019). Jurnal Eksplorasi Akuntansi. 3(1). 203-217.

\section{PENDAHULUAN}

Memasuki tahun baru berarti saatnya memasuki musim pelaporan keuangan. Semua perusahaan yang terdaftar di bursa perdagangan pasar modal diharapkan untuk memenuhi atau mengalahkan perkiraan analis keuangan. Dalam upaya memenuhi harapan beberapa pihak, manajemen perusahaan bermain dalam manajemen laba dikarenakan adanya "hadiah" berupa kompensasi, insentif keuangan, dan prospek promosi yang mana untuk mendapatkan "hadiah" ini tergantung pada kinerja perusahaan yang mereka kelola (P. Saravanan, 2020).

Laporan laba rugi seolah-olah menjadi laporan keuangan yang informasinya terlihat lebih penting dibandingkan jenis laporan keuangan yang lainnya karena terdapat laba yang 
digunakan sebagai parameter kinerja baik atau buruknya suatu perusahaan (Aprilia, 2010). Informasi laba perusahaan menjadi hal penting untuk mengukur kesuksesan atau kegagalan suatu kegiatan bisnis untuk menggapai target operasional yang telah ditentukan yaitu maksimalisasi laba (I. Sadalia dkk, 2017). Hal ini seringkali membuat pihak internal perusahaan atau manajer maupun komisaris merubah laporan keuangan agar terlihat baik, kegiatan inilah yang disebut dengan manajemen laba (earnings management).

Graham dkk (2005) menemukan bahwa pihak manajemen perusahaan bersedia untuk mengubah kebijakan operasi perusahan agar memenuhi target pelaporan keuangan. Salah satu caranya, manajer dapat menghentikan sementara pengeluaran penelitian dan pengembangan (R\&D) untuk menunjukkan untung bukan rugi. Fenomena mengenai manajemen laba bukanlah hal yang baru. Dilansir dari CNBC kasus seperti baru-baru ini berkode emiten AISA atau TPS Food (Tiga Pilar Sejahtera Food ) yang melakukan restatement laporan keuangannya dari tahun 2017-2019 yang banyak ditemukan selisih yang cukup banyak salah satunya penjualan neto dari $\mathrm{Rp}$ 4,92 triliun menjadi hanya $\mathrm{Rp} 1,95$ triliun juga terjadi penggelembungan pendapatan serta penggelembungan pada pos EBITDA dan tidak adanya pengungkapan mengenai transaksi dengan pihak yang berafiliasi bahkan manajemen perusahan membuat dua pembukuan berbeda untuk tujuan eksternal.

El Diri (2018:46) menyatakan bahwa manajer sebagai pihak internal perusahaan memiliki lebih banyak informasi mengenai perusahaan daripada para pemegang saham atau invenstor, hal ini lah yang menimbulkan asimetri informasi. Asimetri informasi disertai kecenderungan berlebih dari pihak eksternal yang lebih terfokus pada informasi laba sebagai indikator kinerja perusahaan, menimbulkan sugesti dalam diri pihak manajemen untuk melakukan penyelewengan dalam mengekspos informasi laba (Agustia, 2013).

Penelitian yang dilakukan Graham, Harvey, dan Rajgopal (2005) memperjelas bahwasanya top management sebagai responden lebih cendrung terlibat dalam manajemen laba riil jika dibandingkan praktik manajemen akrual untuk mencapai target laba. Manajemen laba riil dilakukan dengan mengubah aktivitas operasional aktual, seperti memberikan diskon tunai berlebih, mengurangi biaya R\&D, dan melebihkan produksi (Roychowdhury, 2006). Penelitian terkini tentang praktik manajemen laba menyatakan bahwa cukup penting untuk memahami dengan cara apa perusahaan menjalankan tindakan manajemen laba riil ataupun manajemen laba berbasis akrual (Cohen \& Zarowin, 2010).

Beberapa faktor yang memengaruhi praktik manajemen laba diantaranya strategi bisnis dan financial leverage. Ketatnya persaingan industri manufaktur di Indonesia dengan ditetapkannnya Masyarakat Ekonomi Asean (MEA) dimana produk yang sama harganya sangat kompetitif, perlunya strategi agar produk barang yang dihasilkan industri manufaktur dalam dalam negeri tidak tersaingi oleh produk impor. Strategi bisnis adalah gaya operasional perusahaan, perencanaan terpadu dengan mempertimbangkan aspek strategik dalam perusahaan untuk mencapai target yang diinginkan (Paylosa, 2014:11). Subramanyam dan Tian (2015) mengungkapkan bahwa kompetisi dan persaingan memungkin pihak manajer untuk melakukan tindakan manajemen laba.

Terdapat dua tipe strategi bisnis yang dikemukan oleh Porter (1980), yaitu strategi kepemimpian biaya (Cost Leadership Strategy) atau juga disebut dengan strategi biaya rendah dan strategi biaya berbeda (Differentiation Strategy). Penelitian ini hanya menggunakan strategi kepemimpinan biaya sebagai proksi hal ini didasari oleh penelitian yang dilakukan $\mathrm{Wu}$ et al (2015) perusahaan yang menggunakan strategi bisnis biaya rendah cendrung melakuakan manajemen laba riil dan juga berdasarkan analisa laporan keuangan yang telah dilakukan menyatakan bahwa perusahaan manufaktur lebih banyak menggunakan strategi ini.

Keputusan untuk berhutang menjadi salah satu pilihan untuk perusahaan mendapatkan pendanaan selain penjualan saham. Perusahaan yang melakukan perjanjian hutang memiliki 
keinginan untuk dinilai baik dan mampu membayar utangnya oleh kreditur (Verawati dan Muid, 2012:10). Perusahaan terkadang menipu, seperti meningkatkan margin keuntungan yang dilaporkan, agar dalam negosiasi hutang daya tawar perusahaan meningkat, sehingga meyakinkan kreditor. Financial leverage adalah perusahaan yang menggunakan hutang untuk membiayai asetnya dalam rangka menjalankan kegiatan operasi dan perluasan usahanya, sehingga menghasilkan keuntungan. Widyaningsih (2001) dalam penelitiannya menunjukkan bahwa perusahaan dengan leverage tinggi diduga melakukan manajemen laba karena perusahaan menghadapi ancaman gagal bayar, yaitu tidak dapat memenuhi kewajiban pembayaran hutangnya tepat waktu.

Lemahnya penerapan corporate governance bisa menjadi celah pihak manajemen memanipulasi laporan. Banyak penelitian yang menunjukkan bahwa ciri utama dari lemahnya tata kelola perusahaan adalah perilaku egois pejabat perusahaan dalam hal ini manajer, direktur, dan komisaris. Mekanisme pemantauan yang dirancang untuk mengoordinasikan berbagai kepentingan ini dapat digunakan untuk meminimalkan perilaku manipulatif manajer yang berasal dari konflik kepentingan. Dengan menerapkan mekanisme good corporate governance salah satunya dapat diminimalisir.

Menurut penelitian Akbar Roy (2017), tata kelola perusahaan yang baik akan memperlemah dampak financial leverage terhadap manajemen laba. Hal ini menunjukkan bahwa tindakan oportunistik manajer untuk tindakan manajemen laba dapat ditekan dengan adanya tata kelola perusahaan yang baik. Salah satu mekanisme corporate governance yang mengontrol perilaku manajemen laba adalah kepemilikan manajemen atas saham perusahaa. Menurut Ross et al. (1999) Semakin besarnya kepemilikan saham perusahaan oleh manajemen membuat manajemen berusaha meningkatkan kinerjanya untuk kepentingan pemegang saham dan kepentingan pribadi. Dengan mengelola kepemilikan, kepentingan pemilik atau pemegang saham dapat diselaraskan dengan kepentingan manajer (Jensen dan Meckling, 1976).

Terdapat hasil yang tidak konsisten mengenai dampak financial leverage dan strategi bisnis pada manajemen laba pada penelitian terdahulu. Penelitian sebelumnya hanya menguji pengaruh langsung antara strategi bisnis dan financial leverage terhadap manajemen laba riil. Masih sangat terbatas penelitian yang mempertimbangkan peran variabel moderasi yang dapat memperkuat atau memperlemah pengaruh financial leverage dan strategi bisnis terhadap manajemen laba riil. Mengisi rumpang (gap) tersebut, selain menguji secara empiris pengaruh dari financial leverage dan strategi bisnis terhadap manajemen laba riil, penelitian ini bertujuan untuk melihat peran corporate governance dalam memoderasi pengaruh financial leverage dan strategi bisnis terhadap manajemen laba riil. Berdasarkan penelitian Andrianto dan Anis (2014) untuk meminimalisir terjadinya tindakan manajemen laba salah satu cara yang bisa mencegah adalah dengan memperbesar porsi kepimilikan saham pihak manajemen.

Data penelitian yang digunakan adalah laporan tahunan perusahaan manufaktur yang terdaftar di Bursa Efek Indonesia, untuk mendapatkan hasil penelitian yang spesifik terhadap suatu industri dan untuk mengurangi bias pengukuran pada manajemen laba yang dipengaruhi oleh kelebihan produksi (overproduction) yang mana syarat data ada pada persediaan sehingga lebih cocok menggunakan industri manufaktur.

\section{REVIU LITERATUR DAN HIPOTESIS Agency Theory}

Teori keagenan juga disebut sebagai teori principal-agent, yang dicetuskan oleh Jensen and Meckling (dalam El Diri, 2018:6). Mereka mengasumsikan bahwa ada dua pihak yang terlibat dalam kontrak kerja: agen (manajer) dan prinsipal (pemegang saham). Masalah utama antara prinsipal dan agen adalah masalah informasi. Manajer lebih banyak memiliki 
informasi tentang perusahaan daripada pemegang saham, asimetri informasi ini memberikan celah kepada pihak manajemen untuk melakukan manajemen laba dan menyesatkan pemegang saham.

Harris dan Raviv (dalam El Diri, 2018:47) menyatakan bahwa perbedaan motivasi dan tindakan terhadap risiko dari para pembuat keputusan yang berbeda menuntun pada masalah insentif yang juga berkontribusi pada masalah agensi. Asimetri informasi dapat menyebabkan sejenis "penyakit" yang disebut dengan moral hazard dan adverse selection. Moral hazard merupakan perilaku manajer yang menciderai informasi dikarenakan manajer lebih mengutamakan kepentingan pribadinya sehingga relatif tidak sesuai dengan pedoman etika yang baik, adverse selection adalah prilaku manajer dalam memilih informasi mana yang boleh atau tidak boleh diungkapkan (Winny dan Agustinus, 2017).

Adverse selection dan moral hazard memunculkan masalah koordinasi dalam membuat keputusan mengenai informasi apa yang dilaporkan, bagaimana informasi itu dikomunikasikan, dan siapa yang membuat keputusan. Dengan demikian, pemegang saham mendelegasikan tugas pengambilan keputusan kepada manajer sambil mencoba mempertahankan kontrol atas kinerja mereka. Prinsipal umumnya lebih suka hadiah tinggi dan acuh tak acuh terhadap upaya agen. Di sisi lain, agen memiliki keterampilan membuat keputusan, suka mendapatkan hasil tinggi dan mengeluarkan lebih sedikit usaha.

\section{Pecking Order Theory}

Myers dan Majluf (1984) dalam Pecking Order Theory (POT) mengatakan ada tiga alternatif pendanaan dalam perusahan pertama, pendanaan dari internal yaitu laba ditahan kedua, melalui hutang ketiga, menerbitkan ekuitas baru. Pecking Order Theory ini penting karena memberi sinyal kepada publik bagaimana kinerja perusahaan. Jika sebuah perusahaan membiayai dirinya sendiri secara internal, itu berarti ia kuat. Jika perusahaan mendapatkan pendanaan dari utang menandakan perusahaan tersebut mampu memenuhi kewajibannya. Perusahaan yang dana internalnya tidak mampu memenuhi untuk pengembangan perusahaan maka opsi yang lebih dipilih pihak manajamen adalah dengan berhutang dibandingkan dengan menerbitkan saham baru dikarenakan biaya yang lebih tinggi dan risiko yang ditanggung lebih besar dibandingkan dengan berhutang.

Pecking Order Theory ini muncul dari konsep asimetri informasi. Manajer perusahaan biasanya memiliki lebih banyak informasi mengenai kinerja, prospek, risiko, dan prospek masa depan perusahaan daripada pengguna eksternal seperti kreditor dan investor (pemegang saham). Pecking Order Theory berkaitan dengan alasan munculnya praktik manajemen laba, karena praktik manajemen laba disebabkan oleh kuatnya dorongan permintaan modal eksternal. Oleh karena itu, dalam pelaporan keuangan, manajemen terdorong untuk melakukan manipulasi.

\section{Manajemen Laba}

Ronen dan Yaari (dalam El Diri,2018:7) memberikan definisi yang komprehensif untuk manajemen laba yang membedakan antara dua kegiatan utama yaitu manipulasi laba riil dan manipulasi laba akrual serta menunjukkan bahwa aktivitas semacam itu tidak selalu buruk setiap saat. "Manajemen laba adalah seperangkat keputusan manajemen yang menghasilkan manfaat maksimalisasi nilai jangka pendek yang tidak dilaporkan yang diketahui manajemen.

Manajemen laba dapat bermanfaat karena dapat menunjukkan nilai jangka panjang. Jika menyembunyikan nilai jangka pendek atau jangka panjang, itu merusak; jika menunjukkan kinerja jangka pendek yang nyata, itu tetap netral. Manajemen laba berasal dari mengambil tindakan produksi / investasi sebelum merealisasikan laba, atau membuat pilihan akuntansi yang memengaruhi total pendapatan dan interpretasinya. 
Defenisi manajemen laba menurut Roychowdhury (2006, hal. 336) adalah:

"Tindakan manajemen yang menyimpang dari praktik bisnis normal, dilakukan dengan tujuan utama untuk memenuhi ambang pendapatan tertentu".

Manajemen laba yang sebenarnya melibatkan keputusan ekonomi, seperti mempercepat penjualan melalui kondisi kredit yang longgar dan diskon pelanggan yang lebih tinggi. Cohen dan Zarowin (2010) mengelola penjualan aset jangka panjang dan investasi dalam periode berpenghasilan rendah (Bartov, 1993), mengurangi biaya tetap unit, biaya variabel, dan biaya penjualan (Chi et al., 2011), dan memanipulasi R\&D, periklanan, penjualan, dan manajemen Beban (Osma, 2009).

\section{Strategi Bisnis}

Menurut Porter strategi bisnis berguna untuk menguji daya saing dalam industri agar mendapatkan posisi terbaik di pasar serta keberlanjutan usaha. Agar perusahaan memperoleh dana eksternal dalam memenangkan persaingan perbankan, perlu merumuskan strategi bisnis yang jelas dan tepat guna mencapai kinerja yang lebih baik dalam persaingan yang semakin kompetitif.

Cost leadership strategy ini dipraktikkan lewat penghematan aset (memaksimalkan kemampuan aset tetap untuk menghasilkan output yang diinginkan) serta efisiensi biaya (memaksimalkan input untuk menghasilkan output yang diinginkan) (David et al., 2002). Strategi kepemimpinan biaya berarti kegiatan dan tujuan operasional yang sama, tetapi efisiensi yang dihasilkan lebih tinggi dari pesaing Porter, 1996 (Banker et al., 2011). Perusahaan yang menerapkan strategi kepemimpinan biaya dapat mencapai hal ini dengan "memotong biaya melalui pengalaman, pengendalian biaya dan overhead yang ketat, dan meminimalkan biaya dalam R\&D, periklanan, dan penjualan." (Porter, 1980, Banker et al., 2011).

\section{Financial Leverage}

Financial leverage adalah penggunaan uang yang dipinjam (hutang) untuk membiayai pembelian aset dengan harapan pendapatan atau capital gain dari aset baru akan melebihi biaya pinjaman. Dalam kebanyakan kasus, penyedia hutang akan membatasi seberapa besar risiko yang siap diambil dan menunjukkan batas sejauh mana leverage yang akan diizinkan. Dalam kasus pinjaman arus kas, kelayakan kredit umum perusahaan digunakan untuk mendukung pinjaman tersebut. Perusahaan yang nilai hutangnya terlalu besar cenderungan melanggar perjanjian utang jika dibandingkan dengan perusahaan yang nilai hutangnya lebih kecil (Mardiyah, 2005). Jensen dan meckling (1976) menyatakan bahwa jumlah leverage dalam struktur modal perusahaan memengaruhi pilihan manajer atas aktivitas operasi perusahaan.

\section{Good Corporate Governance}

Good corporate governance merupakan rangkaian sistem yang diterapkan untuk membatasi munculnya masalah asimetri informasi yang dapat mengakibatkan manajemen laba (Guna dan Herawaty, 2010). Survei akademik terbaru tentang tata kelola perusahaan mendefinisikannya sebagai berikut: "Tata kelola perusahaan berkaitan dengan cara-cara pemasok keuangan (investor dan kreditur) kepada perusahaan meyakinkan diri mereka sendiri untuk mendapatkan pengembalian atas investasi mereka. Bagaimana apakah pemasok keuangan meminta manajer mengembalikan sebagian laba kepada mereka, bagaimana mereka memastikan bahwa manajer tidak mencuri modal yang mereka suplai atau berinvestasi dalam proyek yang buruk serta bagaimana para pemasok keuangan mengendalikan para manajer. 


\section{Strategi Bisnis dengan Mananjemen Laba Riil}

Ketatnya persaingan di pasaran membuat perusahaan harus bisa menerapkan strategi yang baik untuk menghadapi persaingan tersebut. Strategi kepemimpinan biaya atau bisa juga disebut strategi biaya rendah biasanya merupakan pemimpin pasar karena lebih murah dibandingkan dengan pesaing dengan produk serupa, sangat memerhatikan tentang penggunaan aset, berkonsentrasi pada efisiensi biaya produksi, (Wu et al, 2015). Tekanan persaingan mengakibatkan meningkatnya tindakan manjemen laba yang dilakukan pihak manajemen perusahaan seperti memangkas biaya penelitian dan pengembangan, mengurangi biaya penjualan dan periklanan atau tindakan lainnnya agar bisa meningkatkan profitabilitas jangka pendek (Karuna, et al 2012).

$\mathrm{Wu}$ et al (2015) menyatakan bahwa perusahaan menggunakan strategi kepemimpinan biaya (cost leadership strategy) melakukan manajemen laba agar mencapai laba tertentu yang menarik minat kreditor dan investor. Perusahaan dengan strategi kepemimpinan biaya akan lebih fokus pada ukuran kinerja jangka pendek sebagai ukuran kinerja pihak manajemen selaku orang yang menjalankan kegiatan operasional perusahan. Singh dan Agrawal (2002) perusahaan dengan strategi kepemimpin biaya diduga memiliki motivasi yang kuat untuk melakukan manajemen laba riil untuk meningkatkan kinerja keuangan mereka. Berdasarkan pemaparan tersebut, maka dapat dirumuskan hipotesis sebagai berikut:

H1: Strategi bisnis berpengaruh positif terhadap manajemen laba riil.

\section{Financial Leverage dengan Manajemen Laba Riil}

Berdasarkan pecking order theory perusahaan lebih memilih pendanaan melalui utang jika pendanaan internal tidak mencukupi. Jika jumlah utang lebih besar dari jumlah aset perusahaan, maka perusahaan juga akan menghadapi risiko besar dalam melunasi utang. Rasio leverage yang tinggi menunjukkan tingginya ketergantungan perusahaan kepada pihak eksternal (kreditor) dan beban biaya hutang (biaya bunga) yang harus dibayar perusahaan (Ari Christianti, 2006). Hasil penelitian Halim et al. (2005) menunjukkan bahwa terdapat hubungan positif yang sangat signifikan antara leverage dan manajemen laba. Hal ini menunjukkan bahwa jika tingkat hutang perusahaan tinggi, para manajer seringkali mengambil langkah-langkah manajemen laba untuk menghindari terjadinya pelanggaran kontrak hutang. Berdasarkan penjelasan tersebut maka dapat dibuat asumsi-asumsi sebagai berikut:

H2: Financial leverage berpengaruh positif terhadap manajemen laba riil.

\section{Corporate Governance Mempengaruhi Strategi Bisnis, Financial Leverage Terhadap Manajemen Laba Riil}

Teori keagenan merupakan perspektif penting yang memicu diskusi tentang tata kelola perusahaan dan manajemen laba (Arslan, 2020). Teori keagenan percaya bahwa "tata kelola perusahaan yang baik" dapat meminimalkan masalah manajemen laba (Kusumawati et al., 2015). Corporate governance muncul sebagai usaha untuk mengontrol atau mengatasi tindakan manajemen yang oportunistik dengan cara membuat suatu sistem dan alat kontrol agar tercipta efisiensi bagi perusahaan yang akan memberikan keuntungan bagi semua pihak. Kepemilikan manajerial dapat memberikan pengaruh dalam membuat keputusan untuk menetapkan kebijakan dan metode akuntansi yang akan diaplikasikan dalam perusahaan (Lukviarman, 2016).

Kepentingan pemegang saham dan manajer tidak selalu selaras. Manajemen harus berhati-hati saat mengambil keputusan agar perusahaan tidak mengalami kerugian. Semakin besar kepemilikan manajer, maka manajer akan berusaha maksimal meningkatkan kinerjanya untuk kepentingan pemegang saham dan untuk kepentingan dirinya sendiri agar laba perusahaan meningkat, karena manajer memiliki bagian atas laba yang diperoleh (Jensen \& 
Meckling, 1976) karena manajer pun merupakan pemilik perusahaan (pemegang saham). Oleh karena itu, semakin tinggi tingkat kepemilikan manajemen yang dimiliki suatu perusahaan maka diharapkan dapat meminimalkan praktek manipulasi aktivitas yang sebenarnya. Berdasarkan penjelasan dan kasus yang dibahas sebelumnya, bahwa:

H3: Corporate Governance membuat strategi bisnis berpengaruh negatif terhadap tindakan manajemen laba riil

H4: Corporate Governance membuat financial leverage berpengaruh negatif terhadap tindakan manajemen laba riil

\section{Kerangka Konseptual}

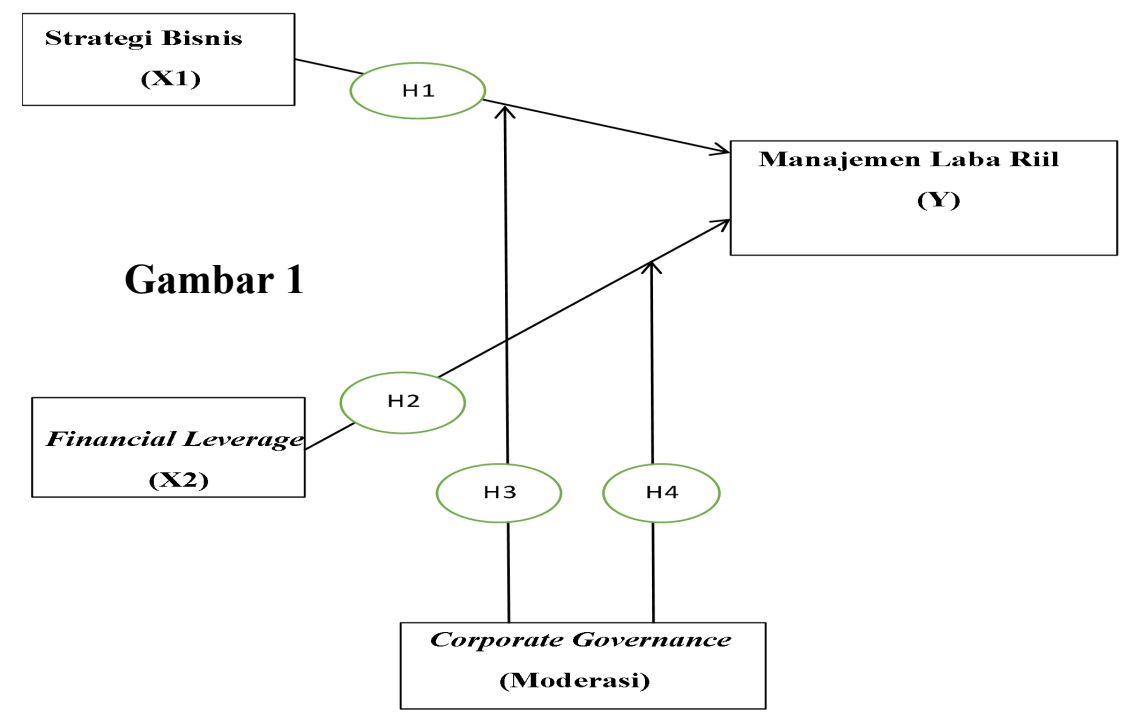

\section{METODE PENELITIAN}

Penelitian asosiasi kausal merupakan penelitian yang dirancang untuk menganalisis hubungan antara satu variabel dengan variabel lainnya atau bagaimana suatu variabel mempengaruhi variabel lain (Sugiyono, 2007). Populasi penelitian ini adalah seluruh perusahaan manufaktur yang terdaftar di Bursa Efek Indonesia dari tahun 2016 hingga 2019. Besar sampel penelitian ini adalah 144 perusahaan manufaktur. Sampel yang diteliti dalam penelitian ini dilakukan melalui metode purposive sampling, dimana sampel dipilih berdasarkan pertimbangan subjektif penelitian dan harus memenuhi persyaratan sebagai standar.

\section{Pengukuran Variabel}

Variabel penelitian ini memiliki satu variabel dependen yaitu manajemen laba. Pengukuran manajemen laba riil mengacu pada penelitian sebelumnya (Roychowdhury 2006; Cohen et al. 2008; Kouaib dan Jarboui 2017) diukur menggunakan 3 proksi yang kemudian hasil dari masing-masing proksi dijumlahkan untuk mencangkup efek keseluruhan proksi manipulasi aktivitas riil.

Manipulasi Penjualan (abnormal cash flow operation):

$$
\frac{\mathrm{CFOt}}{\mathrm{At}-1}=\beta 1\left(\frac{1}{\mathrm{At}-1}\right)+\beta 2\left(\frac{\mathrm{St}}{\mathrm{At}-1}\right)+\beta 3\left(\frac{\Delta \mathrm{St}}{\mathrm{At}-1}\right)+\varepsilon \mathrm{t}
$$


Keterangan

CFOt : Periode operasi arus kas, dibagi dengan total Assett-1,

St : Penjualan pada periode saat ini

$\Delta \mathrm{St} \quad$ : Selisih penjualan pada periode saat ini dengan periode sebelumnya.

Overproduksi (abnormal production costs):

$$
\left.\frac{\text { PRODt }}{\mathrm{At}-1}=\beta 1\left(\frac{1}{\mathrm{At}-1}\right)+\beta 2\left(\frac{\mathrm{St}}{\mathrm{At}-1}\right)+\beta 3\left(\frac{\Delta \mathrm{St}}{\mathrm{At}-1}\right)+\beta 4\left(\frac{\Delta \mathrm{St}-1}{\mathrm{At}-1}\right)\right)+\varepsilon \mathrm{t}
$$

Keterangan

PRODt: COGSt $+\Delta \mathrm{INVt}$,

PRODt: Biaya produksi periodik, dibagi dengan total Assett-1,

St : Penjualan padasaat iniperiode

$\Delta \mathrm{St} \quad$ : Selisih antara penjualan periode berjalan dengan periode sebelumnya

$\Delta$ St-1 : Perbedaan penjualan pada periode $\mathrm{t}-1$ dan $\mathrm{t}-2$.

Pengeluaran Diskresioner (abnormal discretionary expense):

$$
\frac{D I E X P t}{A t-1}=\beta 1\left(\frac{1}{A t-1}\right)+\beta 2\left(\frac{S t-1}{A t-1}\right)+\varepsilon t
$$

Keterangan

DIEXPt : Pengeluaran diskresioner $(\mathrm{R} \& \mathrm{D}$, biaya penjualan, biaya umum dan administrasi) pada periode tersebut, dibagi dengan total Assett-1,

St-1 : Penjualan pada periode sebelumnya.

Terdapat dua variabel independen dalam penelitian ini yang pertama yaitu: strategi bisnis. Asset Turnover of Operation (ATO) merupakan salah satu indikator kunci untuk mengukur cost leadership. Semakin tinggi rasio output terhadap input maka perusahaan semakin dapat memanfaatkan sumber dayanya secara penuh untuk mencapai kesempurnaan operasional, yang menunjukkan cost leadership yang diterapkan oleh perusahaan. Rumus perputaran aset mengacu pada penelitian sebelumnya (Wu et al., 2015).

$$
\text { ATO }(C L)=\frac{\text { Sales }}{\text { Average Total Assets }}
$$

Variabel independen yang kedua adalah financial leverage yang menunjukkan jumlah hutang yang digunakan untuk membiayai aset perusahaan.

$$
\text { Debt to Asset Ratio }=\frac{\text { Total Hutang }}{\text { Total Asset }}
$$

Variabel moderasi dalam penelitian ini yaitu corporate governance yang diukur dengan persentase kepemilikan saham perusahaan oleh pihak manajerial.

$$
\% \text { Kepemilikan manajerial }=\frac{\text { Jumlah kepemilikan saham pihak manajerial }}{\text { Total saham beredar }}
$$

\section{Model Regresi}

Pengujian hipotesis pada penelitian ini menggunakan regresi berganda. Regresi berganda umumnya menjelaskan hubungan antara variabel independen atau prediktor ganda 
dan satu variabel dependen atau kriteria. Variabel dependen dimodelkan sebagai fungsi dari beberapa variabel independen dengan koefisien yang sesuai, bersama dengan istilah konstan. Regresi berganda membutuhkan dua atau lebih variabel prediktor, dan inilah mengapa disebut regresi berganda.

$$
Y(R E M i t)=\alpha+\beta 1(S B)+\beta 2(L E V)+\beta 3(C G)+\beta 4(S B * C G)+\beta 5(L E V * C G)+e
$$

Keterangan:

Y (REMit) : Manajemn Laba Riil

SB : Strategi bisnis

DAR : Debt to asset ratio (Leverage)

CG : Corporate Governance

$\beta 1 \beta 2 \beta 3 \beta n$ : Koefisien

\section{HASIL DAN PEMBAHASAN}

Tabel 1

Statistik Deskriptif

\begin{tabular}{lllll}
\hline Variabel & Minimum & Maximum & Mean & $\begin{array}{l}\text { Std. } \\
\text { Deviation }\end{array}$ \\
\hline REM & 0,002 & 1,730 & 0,591 & 0,319 \\
CL & 0,118 & 4,893 & 1,337 & 0,797 \\
LEV & 0,090 & 1,000 & 0,449 & 0,192 \\
CG & 0,000 & 37,370 & 2,641 & 7,068 \\
N = 80 & & & & \\
\hline Sumber: Data Diolah 2020 & & &
\end{tabular}

\section{Uji Koefesien Determinasi (Adjusted $\mathbf{R}^{2}$ )}

Pengujian ini bertujuan untuk mengukur kemampuan model dalam menjelaskan perubahan variabel dependen yang dapat dilihat dari nilai Adjusted $\mathrm{R}^{2}$. Kisaran koefisien determinasi adalah 0 sampai 1 . Jika $\mathrm{R}^{2}=0$, maka tidak ada hubungan antara variabel bebas dan variabel terikat. Pada saat yang sama, jika $\mathrm{R}^{2}=1$, maka terdapat hubungan yang sempurna.

Tabel 2

Hasil uji determinasi

\begin{tabular}{lc}
\hline \multicolumn{1}{c}{ Predictor } & Adjusted $\boldsymbol{R}$ Square \\
\hline (Constant), SB, LEV, CG, & 0,485 \\
SB*CG, LEV*CG & \\
Sumber: Data Diolah 2020 &
\end{tabular}

Nilai R Square yang adalah 0,485. Hal ini menunjukkan bahwa variabel independen yang terdiri dari strategi bisnis dan leverage keuangan yang disesuaikan dengan tata kelola perusahaan hanya memiliki kemampuan 48,5\% dalam menjelaskan perubahan variabel dependen, sedangkan 51,5\% sisanya dijelaskan oleh faktor lain yang tidak diteliti dalam penelitian ini. 


\section{Uji F}

Uji F digunakan untuk mengetahui apakah model yang digunakan dalam penelitian bersifat signifikan atau tidak, sehingga dapat ditarik kesimpulan apakah model tersebut bisa digunakan untuk memprediksi pengaruh variabel secara bersama-sama terhadap variabel dependen. Hipotesis untuk uji F adalah:

a) $\mathrm{H} 0: \beta=0$, berarti model regresi tidak layak.

b) $H 1: \beta \neq 0$, berarti model regresi layak.

Tabel 3

Uji F

\begin{tabular}{|c|c|c|c|c|c|c|}
\hline \multicolumn{2}{|c|}{ Model } & Sum of Square & $d f$ & Mean Squre & \multirow[t]{2}{*}{$\mathbf{F}$} & \multirow[t]{2}{*}{ Sig. } \\
\hline \multirow{3}{*}{ I } & Regression & 16,095 & 5 & 3,219 & & \\
\hline & Residual & 16,55 & 314 & 0,053 & 61,076 & 0,000 \\
\hline & Total & 32,645 & 314 & & & \\
\hline
\end{tabular}

Sumber: Data Diolah 2020

Berdasarkan tabel dapat disimpulkan bahwa model yang digunakan dalam penelitian layak digunakan.

\section{Uji statistik T}

Tabel 4

Uji T

\begin{tabular}{|c|c|c|c|c|c|}
\hline \multicolumn{2}{|c|}{ Model } & \multicolumn{2}{|c|}{$\begin{array}{c}\text { Unstandardized } \\
\text { Coefficients } B\end{array}$} & \multirow{2}{*}{$\begin{array}{c}\begin{array}{c}\text { Standardized } \\
\text { Coefficients }\end{array} \\
\text { Beta } \\
\end{array}$} & \multirow[t]{2}{*}{ Kes impulan } \\
\hline & & B & Std. Error & & \\
\hline \multirow[t]{5}{*}{1} & (Constant) & 0,130 & 0,042 & & \\
\hline & SB & 0,276 & 0.017 & 0,689 & 0,000 Signifikan \\
\hline & LEV & 0,196 & 0,071 & 0,118 & 0,006 Signifikan \\
\hline & $\mathrm{SB}^{*} \mathrm{CG}$ & 0,001 & 0,003 & 0,019 & 0,855 Tidak signifikan \\
\hline & $\mathrm{LEV}^{*} \mathrm{CG}$ & $-0,150$ & 0,009 & $-0,190$ & 0,102 Tidak signifikan \\
\hline
\end{tabular}

b. Dependent Variable : MANAJEMEN LABA

Sumber : Data Diolah 2020

\section{Pengujian hipotesis 1}

Hasil analisis menunjukkan bahwa strategi bsinis memiliki $\beta$ sebesar 0,276 dengan tingkat signifikansi $0,000<0,05$ artinya bahwa SB secara parsial berpengaruh signifikan positif terhadap manajemen laba riil. Dengan demikian dapat dikatakan bahwa hipotesis pertama (H1) diterima. Hasil ini menunjukkan bahwa perusahaan yang menerapkan strategi binis dengan kepemimpinan biaya cendrung melakukan tindakan manajemen laba.

\section{Pengujian hipotesis 2}

Hasil analisis menunjukkan bahwa financial leverage memiliki $\beta$ sebesar 0,196 dengan tingkat signifikansi $0,006<0,05$ artinya bahwa secara parsial financial leverage berpengaruh signifikan positif terhadap manajemen laba riil. Dengan demikian dapat dikatakan bahwa hipotesis kedua $(\mathrm{H} 2)$ diterima. 


\section{Pengujian hipotesis 3}

Corporate govevrnance memoderasi pengaruh strategi bisnis terhadap nilai manajemen laba riil memiliki $\beta$ sebesar sebesar 0,001 . Tingkat signifikansi $0,855>0,05$. Hal ini menunjukkan bahwa corporate govevrnance tidak memperlemah pengaruh pengaruh strategi bisnis terhadap manajemen laba riil, sehingga hipotesis ketiga (H3) ditolak.

\section{Pengujian hipotesis 4}

Corporate govevrnance memoderasi pengaruh financial leverage terhadap nilai manajemen laba riil memiliki $\beta$ sebesar -0,150. Hal ini menunjukkan bahwa variabel leverage perusahaan (LEV) yang dimoderasi oleh corporate governance berpengaruh negatif terhadap tindakan manajemen laba riil namun tidak signifikan 0,102 >0,05. Hal ini menunjukkan bahwa CG memperlemah pengaruh leverage terhadap nilai manajemen laba riil namun tidak signifikan, sehingga hipotesis keempat (H4) ditolak.

\section{Pengaruh strategi bisnis terhadap manajemen laba riil}

Hasil tersebut dapat disimpulkan semakin besar nilai strategi bisnis maka tingkat manajemen laba riil yang dilakukan pihak manajemen perusahaan dalam laporan keuangan semakin besar. Hasil penelitian ini sejalan dengan penelitian yang dilakukan Peng Wu dkk (2015) dan Winny, Agustinus (2017) yang membuktikan strategi bisnis dengan strategi kepemimpinan biaya memengaruhi manajemen laba riil. Pengaruh variabel strategi bisnis terhadap tindakan manajemen laba tidak terlalu besar dikarenakan penjualan rata-rata pada perusahaan manufaktur yang diteliti berkisar 10 triliun dalam satu periode.

Penjualan pada industri manufaktur ini cukup variatif berkisar dari puluhan miliar hinnga ratusan triliun. Cara untuk memperbesar pengaruh strategi bisnis terhadap manajemen laba riil perusahaan adalah dengan lebih meningkatkan penjualan dengan jumlah aset yang sama atau lebih memaksimalkan lagi asset yang ada untuk menghasilkan penjualan yang lebih.

\section{Pengaruh financial leverage terhadap manajemen laba riil}

Berdasarkan pengujian yang dilakukan pada perusahaan manufaktur pada periode penelitian ini menunjukkan hasil analisis statistik bahwasanya financial leverage berkorelasi positif dan signifikan dengan tindakan manajemen laba riil, dimana semakin besar tingkat leverage maka tindakan manajemen laba riil yang dilakukan pihak manajemen perusahaan dalam laporan keuangan semakin besar.

Hasil analisis statistik menggambarkan bahwa variabel financial leverage berpengaruh hanya sebesar 0,196 (19,6\%) terhadap manajemen laba riil. Hal ini berarti perusahaan manufaktur yang diteliti pada periode tersebut memiliki rasio leverage yang tidak terlalu besar dimana rata-rata hanya $44,9 \%$ atau jumlah asset yang dimiliki kurang dari 50\% yang dibiayai dari utang. Upaya untuk meningkatkan pengaruh financial leverage terhadap tindakan manajemen laba dengan cara meningkatkan rata-rata rasio leverage perusahaan artinya jika jumlah hutang perusahaan mendekati jumlah total nilat aset yang dimiliki perusahaan maka pihak manajemen akan semakin melakukan manajemen laba.

Semakin dekat perusahaan untuk melanggar kontrak utang berbasis akuntansi, semakin besar kemungkinan manajer perusahaan akan memilih aktivitas produksi perusahaan yang mengakibatkan laba yang dilaporkan menjadi lebih tinggi (Watts and Zimmerman, 1986). Data penelitian menunjukkan bahwa perusahaan manufaktur yang menjadi sampel sangat bergantung pada hutang dalam membiayai aset perusahaannya, oleh karena itu apabila terjadi perubahan tingkat hutang maka perlu untuk mempengaruhi kebijakan profitnya. 


\section{Corporate Governance membuat strategi bisnis berpengaruh negatif terhadap tindakan manajemen laba riil.}

Hipotesis ketiga dalam penelitian ini adalah dengan adanya corporate governance membuat hubungan strategi bisnis terhadap manajemen laba riil menjadi negatif. Kontradiktif dengan hipotesis, hasil penelitian ini menunjukkan koefisien regresi hipotesis ini sebesar positif $0,001(1 \%)$ hal ini dapat diartikan bahwa dengan adanya variabel corporate governance membuat hubungan strategi bisnis terhadap manajemen laba riil menjadi positif namun tidak signifikan. Variabel corporate governance dihitung menggunakan persentasi kepemilikan saham oleh pihak manajerial. Hasil yang tidak signifikan disebabkan rata-rata kepemilikan saham oleh pihak manajerial yang relatif kecil yakni sekitar 2,6\% dari total saham perusahaan yang beredar namun dengan jumlah tersebut cukup mampu memberikan pengaruh kepada pihak manajemen untuk melakukan tindakan manajemen laba.

\section{Corporate Governance membuat financial leverage berpengaruh negatif terhadap tindakan manajemen laba riil.}

Hipotesis keempat dalam penelitian ini adalah dengan adanya corporate governance membuat hubungan financial leverage terhadap manajemen laba riil menjadi negatif, dimana dengan adanya corporate governance akan mengurangi terjadinya manajemen laba. Koefisien regresi pada hipotesis ini sebesar $-0,150(-1,5 \%)$ artinya, hasil penelitian ini membuktikan bahwa dengan adanya corporate governance membuat pengaruh financial leverage terhadap tindakan manajernen laba riil menjadi negatif namun tidak sigfinikan. Hal ini bisa terjadi dikarenakan kepemilikan manajerial yang dijadikan proksi dalam mengukur corporate governance pada penelitian ini rata-rata relatif kecil hanya $2,6 \%$ pihak manajerial memiliki saham perusahaan yang mereka kelola.

Penelitian ini sama dengan hasil penelitian yang dilakukan Rahmah \& Soekotjo (2017) yang menyatakan bahwa dengan adanya corporate governance membuat pengaruh leverage terhadap terjadinya praktik manajemen laba menjadi negatif namun tidak signifikan. Hal ini menyebabkan implementasi CG secara langsung tidak bisa diukur kesuksesannya jika hanya mengandalkan kepemilikan manajerial saja atau kepemilikan rata-rata saham oleh pihak manajerial yang relatif kecil. Persentasi kepemilikan saham yang lebih banyak lagi oleh pihak manajerial memungkinkan akan memberikan hasil yang lebih signifikan.

\section{SIMPULAN}

Penelitian yang telah dilakukan menunjukkan bahwa strategi bisnis, financial leverage disertai dengan adanya moderasi corporate governance hanya mampu mempengaruhi tindakan manajemen laba riil sebesar 48,5\%. Berdasarkan hasil temuan penelitian strategi bisnis mempengaruhi manajamen laba riil positif signifikan namun dengan pengaruh yang tidak terlalu besar, untuk menaikkan pengaruh tersebut perusahaan diharapkan dapat memanfaatkan asset semaksimum mungkin agar biaya produksi menjadi murah sehingga dapat menjual unit yang lebih banyak agar meningkatkan penjualan.

Pengaruh yang tidak terlalu besar juga terjadi pada financial leverage terhadap manajernen laba riil. Hal ini disebabkan data sampel perusahaan yang digunakan rata-rata bisa dikatakan cukup bergantung pada utang untuk mendapatkan asset namun tidak terlalu besar sekitar 44,9\%. Langkah yang harus dilakukan untuk menaikkan pengaruh tersebut maka perusahaan harus meningkatkan penggunaan utang untuk mendapatkan asset.

Corporate governance memengaruhi strategi bisnis positif sedangkan financial leverage negatif terhadap tindakan manajemen laba riil namun tidak signifikan. Hal ini dikarenakan rerata kepemilikan saham oleh pihak manajerial sangat kecil, diharapkan dengan kepemilikan saham yang lebih besar lagi oleh pihak manajerial bisa meningkatkan pengaruh 
corporate governance terhadap hubungan strategi bisnis, financial leverage dengan tindakan manajemen untuk melakukan manajemen laba riil.

Berdasarkan kesirnpulan penelitian yang telah diuraikan, maka saran yang dapat peneliti berikan, yaitu:

(1) Bagi peneliti selanjutnya diharapkan menggunakan proksi yang lebih lengkap dalam mengukur corporate governance.

(2) Perlunya mempertimbangkan proksi yang berbeda untuk mengukur strategi bisnis yang lebih berpengaruh terhadap tindakan manajemen laba.

(3) Sebelum melakukan penelitian, peneliti selanjutnya disarankan untuk memastikan kelengkapan data yang akan digunakan agar tidak menemui kendala dalam penelitian atau pengolahan data.

\section{DAFTAR PUSTAKA}

Agustia, Dian. 2013. Pengaruh Faktor Good Corporate Governance, Free Cash Flow, dan Leverage Terhadap Manajemen Laba. Jurnal Akuntansi dan Keuangan, 15 (1): 27-42.

Andrianto, Rei dan Indrianita Anis. 2014. Pengaruh Struktur Corporate Governance dan Kontrak Hutang Terhadap Praktik Manajemen Laba. E- Journal Akuntansi Fakultas Ekonomi Universitas Trisakti ISSN: 2339-08-32 Vol 1 No. 2, September 2014 Hlm. 68- 88 .

Aprilia, H., MU'ID, D. U. L., \& Mu'id, D. (2010). Indikasi Manajemen Laba Melalui Manipulasi Aktivitas Riil (Studi Empiris pada Perusahaan Right Issue yang Terdaftar di BEI) (Doctoral dissertation, Universitas Diponegoro).

Arslan, M., \& Alqatan, A. (2020). Role of institutions in shaping corporate governance system: evidence from emerging economy. Heliyon, 6(3), e03520.

Banker, R.D., Hu, N., Pavlou, P.A. and Luftman, J. (2011), "CIO reporting structure, strategic positioning, and firm performance", MIS Quarterly, Vol. 35 No. 2, pp. 487504

Bartov, E. (1993). The timing of asset sales and earnings manipulation. The Accounting Review, 68(4), 840-855.

Brigita, W., \& Adiwibowo, A. S. (2017). Pengaruh Strategi Tingkat Bisnis, Persaingan Pasar, dan Leverage terhadap Manajemen Laba. Diponegoro Journal of Accounting, 6(4), $1-13$.

Chi, Pevzner, , L. L., \& M. W., Lisic (2011). Is enhanced audit quality associated with greater real earnings management?, Accounting Horizons, 25(2), 315-335, 2011. Diakses dari SSRN: https://ssrn.com/abstrct=

Christianti, Ari. 2008. Pengujian Pecking Order Theory (POT): Pengaruh Leverage Terhadap Pendanaan Surplus dan Defisit Pada Industri Manufaktur di Bursa Efek Indonesia.

CNBC Indonesia. 2019." Astaga! Tiga Pilar Disebut Gelembungkan Keuangan Rp 4 T".Tersedia pada: https://www.cnbcindonesia.com/market/20190327082221-1763104/astaga-tiga-pilar-disebut-gelembungkan-keuangan-rp-4-t. Diakses pada 3 April 2020.

Cohen, Daniel A. dan Paul Zarowin. 2010. Accrual-Based and Real Earnings Management Activities Around Seasoned Equity Offerings. Journal of Accounting \& Economics Vol. 50 No. 1: 2-19.

David, J.S., Hwang, Y., Pei, B.K., Reneau, J.H., 2002. The performance effects of congruence between product competitive strategies and purchasing management design. Manag. Sci. 48 (7), 866-885.

El Diri, Malik, (2018). Introduction to Earnings Management. Springer International Publishing. Leeds, UK. 
Graham, J.R., Harvey, C.R. and Rajgopal, S. (2005), "The economic implications of corporate financial reporting", Journal of Accounting and Economics, Vol. 40 Nos $1 / 3$, pp. 3-73.

Guna, W. I. and Herawaty, A. (2010). "Pengaruh Mekanisme Good Corporate Governance, Independensi Auditor, Kualitas Audit dan Faktor Lainnya Terhadap Manajemen Laba". Jurnal Bisnis Dan Akuntansi. 12(1): 53-68.

Hrp, A. I., Sadalia, I., \& Fachrudin, K. A. (2017). The Effect of Leverage and Financial Distress on Earnings Management with Good Corporate Governance as the Moderating Variable. Academic Journal of Economic Studies, 3(4), 86-95.

Jensen, M.C. and Meckling, W.H. (1976) 'Theory of the firm: managerial behavior, agency costs and ownership structure', Journal of Financial Economics, Vol. 3, No. 4, pp.305-360.

Karuna, C., Subramanyam, K. R., \& Tian, F. (2015). Competition and earnings management. Working Paper.

Kouaib, A., Anis Jarbouib. (2017). The Mediating Effect of REM on the Relationship Between CEO Overconfidence and Subsequent Firm Performance Moderated by IFRS Adoption: A Moderated-Mediation Analysis. Research in International Business and Finance, 42, 338-352.

Kusumawati, E., Trisnawati, R., \& Mardalis, A. (2015). Pengaruh Corporate Governance Terhadap Manajemen Laba Riil.

Lukviarman, P. N. (2016). Corporate Governance: "Menuju Penguatan Konseptual dan Implementasi di Indonesi"a. Yogyakarta: CV. Solusi Distribusi.

Mardiyah, Aida Ainul. (2005). Pengaruh Struktur Kepemilikan Manajerial, Earnings Management, dan Free Cash Flow terhadap Hutang dan Kinerja. Konferensi Nasional Akuntansi

Myers, S. C. and Nicholas, S. M. (1984). Corporate financing decisions when firms have invest- ment information that investors do not. Journal of Financial Economics, 13(2), 187- 220.

Osma, B., \& Young, S. (2009). R\&D expenditure and earnings targets. The European Accounting Review, 18, 7-32.

Paylosa, Fanny. 2014. "Pengaruh Strategi Bisnis dan Sentralisasi terhadap Hubungan Antara Pemanfaatan Informasi Sistem Informasi Manajemen dan Kinerja Manajerial". Artikel. Universitas Negeri Padang.

Porter, M.E., 1980. Competitive Strategy: Techniques for Analyzing Industries and Competition, p. 300. New York.

1985. Competitive Advantage. New York: Free Press. . 1996. What is strategy? Harvard Business Review 74 (6): 61-78.

Roychowdhury, Sugata. (2006). Earnings Managementthrough Real Activities Manipulation. Journal of Accounting and Economic, 42, 335- 370.

Saravanan, 2020. " Look Out For Cover-Ups In Financial Reports". Tersedia pada: https://www.financialexpress.com/industry/look-out-for-cover-ups-in-financialreports/1993690/. Diakses pada 18 JUNI 2020.

Singh, P. and Agrawal, N.C. (2002), "The effects of firm strategy on the level and structure of executive compensation", Canadian Journal of Administrative Sciences, Vol. 19 No. 1, pp. 42-56.

Sugiyono. 2007. Metode Penelitian Kuantitatif Kualitatif dan R\&D. Bandung: Alfabeta

Verawati, Diana dan Dul Muid. 2012. "Pengaruh Divesifikasi Operasi, Divesifikasi Geografis, Leverage dan Struktur Kepemilikan terhadap Manajemen Laba". 
Widyaningsih, A. U. (2001). Analisis faktor-faktor yang berpengaruh terhadap earnings management pada perusahaan go public di Indonesia. Jurnal Akuntansi \& Keuangan Vol. 3 No. 2 November 2001, 89-101.

$\mathrm{Wu}, \mathrm{P} ., \mathrm{Gao}, \mathrm{L} .$, \& Gu, T. (2015). Business strategy, market competition and earnings management. Chinese Management Studies, 9(3), 401. 